\title{
Quality improvements on creative industry by using Six Sigma: a study case
}

\author{
Dwi Adi Purnama, Riadho Clara Shinta, and Vembri Noor Helia \\ Department of Industrial Engineering, Islamic University of Indonesia, Jl. Kaliurang Km 14.5, Yogyakarta, Indonesia
}

\begin{abstract}
Indonesia has several creative economy sectors that rapidly developed and potentially can be improved to $7 \%$ annually. One of them is textile industry specifically bag industry. This industry's development could enhance the production of commodities and emerge other SMEs to initiate the similar field. Therefore, to raise its profit, customer's satisfaction must be elevated by minimizing defected products. In order to support it, an improvement on production process is a must. This research employs Six Sigma methods integration with Fuzzy Analytical Hierarchy Process (Fuzzy AHP)-Failure Mode and Effect Anlysis (FMEA). Six Sigma is designated to analyze the level of products' defect through Define, Measure, Analyze, Improve, and Control (DMAIC) stages and assess the factors that cause the defects by using Fuzzy AHP decision support system and FMEA in risk analysis on defect. The result of the research shows the shortage of defects that demonstrated by DPMO indicator and Sigma level. It is identified that the number of DPMO was being reduced from 20003.75 to 11185.73 . While Six Sigma level demonstrated the enhancement from 3.61 to 3.86 . Those suggest that the improvement solution provides has significant effect on the defects decreasing at the bag convection industry.
\end{abstract}

\section{Introduction}

In recent modern era, economic matter becomes one of the measurement standards of country's development. World's economic development that could support the worldwide' people life includes Indonesia as one. According to the Indonesian Creative Economy Board, there are several creative economy sectors developed rapidly and potentially to be further advanced. It is stated that there are three sectors, which are fashion, culinary and handcraft [1]. The existing creative industry could sharpen the creativity, skill and individual talent in creating proper welfare and job opportunities by producing and empower one's creation and creativity [2].

In Indonesia, creative industry plays important role in economic growth, by $7 \%$ annual growth [3]. One of the creative industries that rapidly developed is textile industry or handcraft. It is considered popular since there are various of ethnic, race and culture that grow in Indonesia along with its existing natural resources. As illustrated by Central Bureau of Statistics (BPS), the growth of textile industry in Indonesia shows the annual elevation up to 142,72 in 2016 [4].

The development of textile industry, specifically bag convection could push the trade's commodities up and emerge other SMEs to work on the similar fields. As other SMEs actively involves in this sector, hence new innovations will be invented and quality will be improved. It can be fulfilled by providing qualified products and minimizing defect product, which can influence profit percentage. Therefore, profit can be achieved by increasing customers' satisfaction and minimizing defect products [5]. One of the SMEs that produced bag in Yogyakarta is Zano Production that produces innovated bags with make to stock and make to order system and employs 26 workers. Zano production is the case study of this research. In every production process, it still employs conventional process by applying simple technology, material and tools. That possibly triggered products' defect at each process.

This research is objected to minimize the numbers of defects due to existing failures, to enhance customers' satisfaction by using Fuzzy AHP-FMEA and Six Sigma method through phases of Define, Measure, Analyze, Improve and Control (DMAIC). Quality control plays important role to identify product's quality characteristics, by comparing specifications or requirements and taking appropriate actions for differences between its actual performance with the standard [6]. It will be conducted to fulfill customers' service [7]. Most of the Small and Middle Enterprises do not aware on the importance of quality control by using Six Sigma. Moreover, if the management could relate customers' Six Sigma with business strategy [8]. The difference between recent research with the previous ones is the implementation of Six Sigma method that designated to analyze the products' defect level and assess the root cause of the defect, which is integrated with Fuzzy AHP decision support system and FMEA in risk analysis. Therefore, from the assessment, the

\footnotetext{
*Corresponding author: vembri@uii.ac.id
} 
improvement on products could be performed to reduce the defect that will directly enhance their quality.

\section{Methodology}

The research was taken place in SME of Zano Production located in Godean street, Yogyakarta. This research implements Fuzzy AHP-FMEA by using Six Sigma calculation to improve quality. It will be conducted in several stages as described in following figure 1.

\section{Implementation of Six Sigma}

There are five stages in this implementation, which are Define, Measure, Analyze, Improve, and Control that abbreviated with DMAIC. It will be used to measure the quality of products and services as well as to control their quality [9].

\subsection{Stage of Define}

Define is purposed to identify the production process and types of defects in industry [10] This stage is objected to identify defects on bag products based on interview conducted with production manager of Zano Production. There are 3 types of defects that frequently occurred in this company, which are: defects in cutting activity, sewing and embroidery.

\subsection{Stage of Measure}

Measure is conducted by using DPMO (Deffect Per Million Opportunities) to rate the recent company's performance, specifically in quality of management and to calculate sigma level from DPMO. The observation was conducted on 47 batches of bag production with value of DPMO and sigma level are presented on table 3.

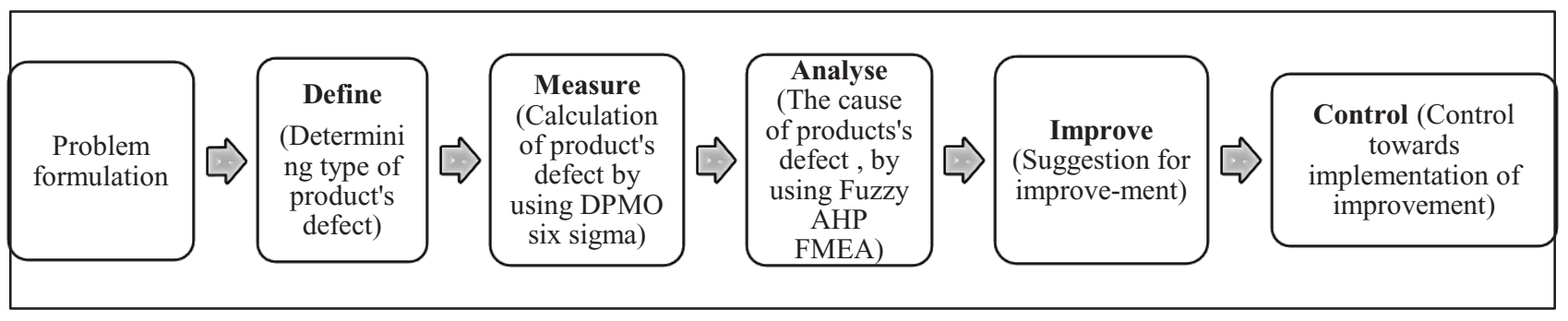

Fig 1. Research stage

Table 1. Recapitulation of products' defect data

\begin{tabular}{|c|c|c|c|c|c|c|c|c|c|}
\hline \multirow[b]{2}{*}{ Batch } & \multirow[b]{2}{*}{ Type } & \multirow[b]{2}{*}{$\begin{array}{c}\text { Amount } \\
\text { of bag }\end{array}$} & \multicolumn{3}{|c|}{ Defect } & \multirow[b]{2}{*}{$\begin{array}{l}\text { Number } \\
\text { of defect }\end{array}$} & \multirow[b]{2}{*}{ DPO } & \multirow[b]{2}{*}{ DPMO } & \multirow[b]{2}{*}{ Sigma } \\
\hline & & & $\begin{array}{c}\text { Sewi } \\
\text { ng }\end{array}$ & $\begin{array}{c}\text { Cutti } \\
\text { ng }\end{array}$ & $\begin{array}{c}\begin{array}{c}\text { Embroi } \\
\text { dery }\end{array} \\
\end{array}$ & & & & \\
\hline 1 & Ladies Bag & 50 & 0 & 3 & 0 & 3 & 0,02 & 20000 & 3,55 \\
\hline 2 & Telkomsel Bag & 60 & 3 & 1 & 1 & 5 & 0,027777 & 27777,77 & 3,41 \\
\hline 3 & Timnas Black Canvas Bag & 125 & 2 & 1 & 0 & 3 & 0,008 & 8000 & 3,91 \\
\hline 4 & Timnas Canvas Bag & 25 & 0 & 1 & 0 & 1 & 0,013333 & 13333,33 & 3,72 \\
\hline 5 & Timnas Black Cordura Bag & 100 & 3 & 2 & 1 & 6 & 0,02 & 20000 & 3,55 \\
\hline 6 & Baby Gray Back Pack Bag & 150 & 8 & 4 & 1 & 13 & 0,028888 & 28888,88 & 3,39 \\
\hline 7 & Pemkot Demak Bag & 35 & 1 & 2 & 0 & 3 & 0,028571 & 28571,42 & 3,40 \\
\hline 8 & Sibalec Bag & 500 & 3 & 1 & 1 & 5 & 0,003333 & 3333,333 & 4,21 \\
\hline 9 & Trolley Bag & 200 & 10 & 10 & 2 & 22 & 0,036666 & 36666,66 & 3,29 \\
\hline 10 & PMI Black Bag & 310 & 5 & 3 & 3 & 11 & 0,011827 & 11827,95 & 3,76 \\
\hline 11 & Ladies Black Vinyl Bag & 31 & 0 & 2 & 0 & 2 & 0,021505 & 21505,37 & 3,52 \\
\hline 12 & Ladies Maroon Vinyl Bag & 31 & 0 & 1 & 0 & 1 & 0,010752 & 10752,68 & 3,79 \\
\hline 13 & Gray Gontor Bag & 50 & 0 & 2 & 0 & 2 & 0,013333 & 13333,33 & 3,72 \\
\hline 14 & Black Gontor Bag & 50 & 0 & 3 & 1 & 4 & 0,026666 & 26666,66 & 3,43 \\
\hline 15 & Brown Gontor Bag & 50 & 0 & 1 & 0 & 1 & 0,006666 & 6666,666 & 3,97 \\
\hline 16 & Black UGM Tote Bag & 30 & 0 & 1 & 1 & 2 & 0,022222 & 22222,22 & 3,51 \\
\hline 17 & Black AFI Bag & 235 & 4 & 3 & 1 & 8 & 0,011347 & 11347,51 & 3,78 \\
\hline
\end{tabular}




\begin{tabular}{|c|c|c|c|c|c|c|c|c|c|}
\hline \multirow[b]{2}{*}{ Batch } & \multirow[b]{2}{*}{ Type } & \multirow[b]{2}{*}{$\begin{array}{c}\text { Amount } \\
\text { of bag }\end{array}$} & \multicolumn{3}{|c|}{ Defect } & \multirow[b]{2}{*}{$\begin{array}{l}\text { Number } \\
\text { of defect }\end{array}$} & \multirow[b]{2}{*}{ DPO } & \multirow[b]{2}{*}{ DPMO } & \multirow[b]{2}{*}{ Sigma } \\
\hline & & & $\begin{array}{c}\text { Sewi } \\
\text { ng }\end{array}$ & $\begin{array}{c}\text { Cutti } \\
\text { ng }\end{array}$ & $\begin{array}{c}\text { Embroi } \\
\text { dery }\end{array}$ & & & & \\
\hline 18 & Blue Supreme Bag & 200 & 3 & 2 & 2 & 7 & 0,011666 & 11666,66 & 3,77 \\
\hline 19 & Green Trolley Bag & 100 & 2 & 4 & 2 & 8 & 0,026666 & 26666,66 & 3,43 \\
\hline 20 & Distro Bag & 160 & 3 & 2 & 3 & 8 & 0,016666 & 16666,66 & 3,63 \\
\hline 21 & Black Distro Sling Bag & 20 & 0 & 0 & 1 & 1 & 0,016666 & 16666,66 & 3,63 \\
\hline 22 & Brown Distro Sling Bag & 20 & 0 & 0 & 2 & 2 & 0,033333 & 33333,33 & 3,33 \\
\hline 23 & Read Waist Bag & 20 & 0 & 1 & 0 & 1 & 0,016666 & 16666,66 & 3,63 \\
\hline 24 & Black Waist Bag & 20 & 0 & 1 & 0 & 1 & 0,016666 & 16666,66 & 3,63 \\
\hline 25 & Green Distro Bag & 126 & 4 & 2 & 3 & 9 & 0,023809 & 23809,52 & 3,48 \\
\hline 26 & Shopper Bag & 50 & 0 & 1 & 1 & 2 & 0,013333 & 13333,33 & 3,72 \\
\hline 27 & PMI Bag & 30 & 1 & 0 & 0 & 1 & 0,01111 & 11111,11 & 3,79 \\
\hline 28 & Juventus Back Pack & 50 & 0 & 1 & 1 & 2 & 0,013333 & 13333,33 & 3,72 \\
\hline 29 & Juventus Sling Bag & 50 & 0 & 2 & 0 & 2 & 0,013333 & 13333,33 & 3,72 \\
\hline 30 & Timnas Waist Bag & 50 & 0 & 3 & 0 & 3 & 0,02 & 20000 & 3,55 \\
\hline 31 & PMI Back Pack & 160 & 1 & 1 & 1 & 3 & 0,00625 & 6250 & 3,99 \\
\hline 32 & Mutu Bag & 150 & 1 & 2 & 1 & 4 & 0,008888 & 8888,888 & 3,87 \\
\hline 33 & Workshop Bag & 1355 & 16 & 8 & 8 & 32 & 0,007872 & 7872,078 & 3,91 \\
\hline 34 & SD Sapen Back Pack & 362 & 3 & 5 & 2 & 10 & 0,009208 & 9208,103 & 3,86 \\
\hline 35 & PMI BPO Bag & 150 & 4 & 2 & 0 & 6 & 0,013333 & 13333,33 & 3,72 \\
\hline 36 & SD Sapen Tote Bag & 350 & 2 & 2 & 0 & 4 & 0,003809 & 3809,523 & 4,17 \\
\hline 37 & Parcel Tote Bag & 100 & 0 & 2 & 1 & 3 & 0,01 & 10000 & 3,83 \\
\hline 38 & Hartono Trolley Bag & 200 & 8 & 4 & 2 & 14 & 0,023333 & 23333,33 & 3,49 \\
\hline 39 & $\begin{array}{l}\text { Pink Yummy Ladies bag } \\
\text { Navy Blue Yummy Ladies }\end{array}$ & 50 & 1 & 2 & 2 & 5 & 0,033333 & 33333,33 & 3,33 \\
\hline 40 & Bag & 50 & 1 & 3 & 0 & 4 & 0,026666 & 26666,66 & 3,43 \\
\hline 41 & Green Yummy Ladies Bag & 50 & 0 & 2 & 0 & 2 & 0,013333 & 13333,33 & 3,72 \\
\hline 42 & Black Yummy Ladies Bag & 50 & 2 & 6 & 3 & 11 & 0,073333 & 73333,33 & 2,95 \\
\hline 43 & Brown Yummy Ladies Bag & 50 & 1 & 3 & 1 & 5 & 0,033333 & 33333,33 & 3,33 \\
\hline 44 & $\begin{array}{l}\text { Maroon Yummy Ladies Bag } \\
\text { Light Blue Yummy Ladies }\end{array}$ & 50 & 1 & 5 & 0 & 6 & 0,04 & 40000 & 3,25 \\
\hline 45 & Bag & 50 & 1 & 4 & 1 & 6 & 0,04 & 40000 & 3,25 \\
\hline 46 & $\begin{array}{l}\text { Blue White Combination } \\
\text { Yummy Ladies }\end{array}$ & 50 & 0 & 3 & 1 & 4 & 0,026666 & 26666,66 & 3,43 \\
\hline 47 & Zano Bag & 250 & 15 & 5 & 0 & 20 & 0,026666 & 26666,66 & 3,43 \\
\hline & & Av & & & & & & 20003,75 & 3,62 \\
\hline
\end{tabular}

To measure the level of six sigma, below calculation can be conducted:

$$
\begin{gathered}
D P O=\frac{\text { Number of Defect }}{(\text { amounts of defect's possibility) } x(\text { numbers of examination })} \\
D P M O=D P O \times 1.000 .000
\end{gathered}
$$

After resuming the value of DPMO, sigma level can be calculated by using following formula.

$$
\text { Sigma Level }=\text { normsinv }\left(\frac{1000000-D P M O}{1000000}\right)+1,5
$$


On every batch, DPMO and Sigma level can be calculated to get overall DPMO value and sigma level from average of 47 production batches. Hence, from average calculation, DPMO valued as 20.003,75361 and sigma level of 3,615702857 . DPMO of 20.003,75361 indicates that in one million chances of bag production, there are 20.003,75361 possibilities of bag for experiencing product's defect.

\subsection{Stage of Analyze}

Analyze stage is carried out to identify the cause of defect on bag production. It was performed by involving Failure Mode and Effect Analysis (FMEA) to identify and assess the risk that turns to be the potential cause of failure [11]. The result of FMEA is shown on table 2.

Table 2. Failure mode and effect analysis

\begin{tabular}{|c|c|c|c|c|c|c|c|c|c|}
\hline $\begin{array}{c}\text { Function } \\
\text { Item }\end{array}$ & $\begin{array}{c}\text { Potential } \\
\text { Failure } \\
\text { Mode } \\
\end{array}$ & $\begin{array}{c}\text { Potential Effect } \\
\text { on Customer } \\
\text { Because of } \\
\text { Defect } \\
\end{array}$ & $\tilde{2}$ & Potential Causes & そ) & $\begin{array}{c}\text { Current Process } \\
\text { Control }\end{array}$ & $\underset{7}{\sin }$ & $\underset{\gtrless}{2}$ & Ranking \\
\hline \multirow{4}{*}{$\begin{array}{l}\text { Level of } \\
\text { Accuracy }\end{array}$} & \multirow{2}{*}{ Sewing } & \multirow{2}{*}{$\begin{array}{l}\text { Bag becomes } \\
\text { easy to break }\end{array}$} & \multirow{2}{*}{7} & $\begin{array}{l}\text { Inappropriateness } \\
\text { of sewing distance } \\
(\mathrm{F} !)\end{array}$ & 6 & $\begin{array}{l}\text { Distance's } \\
\text { adjustment for } \\
\text { sewing process } \\
\text { (F1) }\end{array}$ & 4 & 168 & 2 \\
\hline & & & & $\begin{array}{l}\text { Inappropriateness } \\
\text { on the depth of } \\
\text { sewing (F2) }\end{array}$ & 7 & $\begin{array}{l}\text { No regulation on } \\
\text { the depth of } \\
\text { sewing process } \\
\text { (F2) }\end{array}$ & 8 & 392 & 1 \\
\hline & \multirow[b]{2}{*}{ Cutting } & \multirow{2}{*}{$\begin{array}{c}\text { The lack of } \\
\text { accuracy on the } \\
\text { dimension of the } \\
\text { bag }\end{array}$} & \multirow[b]{2}{*}{8} & $\begin{array}{l}\text { Cutting inaccuracy } \\
\text { based on pattern } \\
\text { (F3) }\end{array}$ & 4 & $\begin{array}{l}\text { Adjustment on } \\
\text { machine's platting } \\
\text { towards pattern } \\
\text { (F3) }\end{array}$ & 3 & 96 & 3 \\
\hline & & & & $\begin{array}{l}\text { The workers are } \\
\text { careless in } \\
\text { employing cutting } \\
\text { machine (F4) }\end{array}$ & 2 & $\begin{array}{l}\text { The workers } \\
\text { should focus in } \\
\text { carrying out the } \\
\text { cutting based on } \\
\text { the pattern (F4) }\end{array}$ & 3 & 48 & 4 \\
\hline \multirow{2}{*}{ Esthetic } & \multirow{2}{*}{ Embroidery } & \multirow{2}{*}{$\begin{array}{l}\text { Less of esthetic } \\
\text { value of the bag }\end{array}$} & \multirow{2}{*}{3} & $\begin{array}{l}\text { Machine's quality } \\
\text { in creating } \\
\text { embroidery (F5) }\end{array}$ & 4 & $\begin{array}{l}\text { Machine's Set up } \\
(\mathrm{F} 5)\end{array}$ & 3 & 36 & 5 \\
\hline & & & & $\begin{array}{l}\text { The workers are } \\
\text { careless in } \\
\text { processing the } \\
\text { embroidery (F6) }\end{array}$ & 2 & $\begin{array}{l}\text { Assisted by using } \\
\text { pattern's molding } \\
\text { (F6) }\end{array}$ & 2 & 12 & 6 \\
\hline
\end{tabular}

Based on above table, it can be identified the occurred risk value and the effect based on the value of RPN. The value of RPN is derived from the result of multiplication between rating severity $(\mathrm{S})$ probability $(\mathrm{P})$, and detectability (D). On the analysis of FMEA, the highest value of RPN (Risk Priority Number) is recorded on the sewing defect due to inappropriateness towards the sewing depth with RPN of 392. But, FMEA only considers 3 types of RPN's assessments equally or similar, which are: severity, probability and detectability, but in real case, the criteria of the risks are weighted differently [12]. Hence, it takes risk analysis criteria weighting by using AHP method (Analytical Hierarchy Process).

Coupled comparison on Analytical Hierarchy Process (AHP) will be more accurate if the comparison scale specified by experts applies fuzzy AHP. It is assumed that AHP method includes high subjectivity. Fuzzy AHP effectively could reduce the human thoughts' unclarity by providing value's interval [13]. There is the weighting comparison's result for AHP and Fuzzy AHP provided by experts in table 3 .

\subsection{Calculation of RPN Value with the Weighting of Fuzzy AHP}

Calculation on RPN (Risk Priority Number) applies the result of Fuzzy AHP's weighting by multiplying RPN's value with Fuzzy AHP's weighting. Therefore, recent RPN's value is verified [14].

$$
\mathrm{RPN}=\left(\mathrm{W}_{\mathrm{S}} \times \mathrm{S}\right)+\left(\mathrm{W}_{\mathrm{O}} \times \mathrm{O}\right)+\left(\mathrm{W}_{\mathrm{D}} \times \mathrm{D}\right)
$$

where: Ws, Wo, and $\mathrm{W}_{\mathrm{D}}$ are the relative weights of severity, occurrence, detectability factors while $\mathrm{S}, \mathrm{O}$, and $\mathrm{D}$ each represented the score of $\mathrm{S}, \mathrm{O}$, and $\mathrm{D}$ value.

The following is the result of multiplication between relative weights with the value of severity, occurrence, and detectability (table 4). 
Table 3. The result of fuzzy AHP weighting comparison

\begin{tabular}{ccr}
\hline Criteria & Weight's Comparison of Initial AHP & Weight's Comparison of Fuzzy AHP \\
\hline Severity & 0,696531334 & 0,845492751 \\
Occurrence & 0,231613959 & 0,269892123 \\
Detectability & 0,071854707 & 0,083141035 \\
\hline
\end{tabular}

Table 4. The result of calculation of RPN on fuzzy AHP-FMEA

\begin{tabular}{ccccccccccc}
\hline No & Code & Severity & Occurrence & Detectability & Ws & Wo & WD & RPN & Ranking \\
\hline 1 & F1 & 7 & 6 & 5 & 0,845492751 & 0,269892123 & 0,083141035 & 7,95350717 & 3 \\
2 & F2 & 7 & 7 & 8 & 0,845492751 & 0,269892123 & 0,083141035 & 8,472822399 & 1 \\
3 & F3 & 8 & 4 & 3 & 0,845492751 & 0,269892123 & 0,083141035 & 8,092933605 & 2 \\
4 & F4 & 8 & 2 & 3 & 0,845492751 & 0,269892123 & 0,083141035 & 7,55314936 & 4 \\
5 & F5 & 3 & 4 & 3 & 0,845492751 & 0,269892123 & 0,083141035 & 3,86546985 & 5 \\
6 & F6 & 3 & 2 & 2 & 0,845492751 & 0,269892123 & 0,083141035 & 3,242544569 & 6 \\
\hline
\end{tabular}

Based on RPN's calculation by considering the weighting using Fuzzy AHP, hence it can be resumed the highest ranking of RPN as 8,472822399 with process code of F2, the sewing defect that caused by sewing depth inappropriateness. It is similar with conventional RPN calculation. Yet, based on the ranking order, after fixing the depth of the sewing, the cutting inappropriateness from pattern should be the next concern. Therefore, it takes improvements for six activities on bag production system that could possibly cause the defect and considers the ranking system on designated risks.

\subsection{Stage of Improve}

After performing the observation towards the cause of defect, then next step is conducting the improvement by determining solution to minimize the defects on bags. Several options that could be taken to overcome defects on products are illustrated by table 5 .

Table 5. Solution on defects of bags

\begin{tabular}{|c|c|c|}
\hline $\begin{array}{l}\text { Potential Failure } \\
\text { Mode }\end{array}$ & Potential Causes & Improve \\
\hline \multirow[t]{2}{*}{ Sewing } & Inappropriateness distance of the sewing & $\begin{array}{l}\text { By using needle from the sewing machine that } \\
\text { already adjusted with the size of the bag. }\end{array}$ \\
\hline & Inappropriateness on the depth of the sewing & Needle's adjustment with the thickness of material \\
\hline \multirow[b]{2}{*}{ Cutting } & The cutting inappropriateness from pattern & $\begin{array}{l}\text { It needs pattern's clamp when performing the } \\
\text { cutting }\end{array}$ \\
\hline & $\begin{array}{l}\text { The workers are careless in employing cutting } \\
\text { machine }\end{array}$ & $\begin{array}{l}\text { It needs clearer pattern by emphasizing lines on } \\
\text { pattern }\end{array}$ \\
\hline \multirow{2}{*}{ Embroidery } & Quality of embroidery's machines & $\begin{array}{l}\text { The workers should conduct the initial set up and } \\
\text { inspection on the machine's readiness before } \\
\text { performing the embroidery process }\end{array}$ \\
\hline & The workers are careless in making the embroidery & $\begin{array}{l}\text { The use of molding to simplify the pattern's } \\
\text { construction }\end{array}$ \\
\hline
\end{tabular}

Table 6. The comparison of DPMO and sigma level before and after improvements

\begin{tabular}{ccc}
\hline Condition & DPMO & Level Sigma \\
\hline Before Improvement & 20003.75 & 3,61 \\
After Improvement & 11185.73 & 3,86 \\
\hline
\end{tabular}




\subsection{The stage of Control}

In this stage, it is conducted the actions of reducing the number of defect's bags by comparing the value of DPMO and Sigma level before and after improvements. Consequently, it is suggested to provide structured improvement actions. Below, is the table covers result's comparison between DPMO value and Sigma level before and after improvements.

\section{Conclusion and Suggestion}

From this research, it can be concluded that the defects occurred the most at Zano Production are the lack of accuracy at the cutting and the sewing as well as at the embroidery process. The value of DPMO before the improvement is 20003.75 while the sigma level is recorded as 3,61.

To reduce those defects, several improvements were conducted, hence the value of DPMO was decreased with difference of 8818,02 and sigma level of 0,25. FMEA table showed that the defects mostly caused by depth inappropriateness on the sewing process. It will decrease the bags' quality that will lead to easily-broken bag with RPN value of 392 while RPN with multiplication of Fuzzy AHP-FMEA counted as 8,472822399. Suggestion that can be delivered to company is by paying more attention to the process of controlling of the bag production that needs structured improvement actions.

\section{References}

1. Munaf, Triawan, KOMPAS.COM. [Online] Available at: http://bisniskeuangan.kompas.com/read/2017/04/13/ 203000326/inilah.tiga.sektor.ekonomi.kreatif.yang.s edang.naik.daun [Accessed 28 Juni 2017] (2017)

2. Kemendag, Studi Industri Kreatif Indonesia. Jakarta: Kementerian Perdagangan Republik Indonesia (2007)

3. Menperin, Kementrian Perindustrian Republik Indonesia. [Online] Available at: http://www.kemenperin.go.id/artikel/12797/Menperi n:-Industri-Kreatif-Tumbuh-7-Per-Tahun [Accessed 28 Juni 2017] (2016)

4. Central Bureau of Statistics (Badan Pusat Statistik), Indeks Produksi Triwulanan Industri Mikro dan Kecil (2010=100) menurut 2-digit KBLI, 2011-2016. [Online] Available

at: https://www.bps.go.id/linkTableDinamis/view/id/97 4 [Accessed 28 Juni 2017] (2016)
5. BisnisUKM, BisnisUKM.COM. [Online] Available at $\quad$ http://bisnisukm.com/strategi-meningkatkankepuasan-pelanggan.html [Accessed 28 Juni 2017] (2017)

6. M. Djunaidi, A. Suryadarmawan V, Pengendalian dan Perbaikan Kualitas Produk Kawat Baja dengan Metode Aplikasi Six Sigma (DMAIC) dan Kaizen $(5 \mathrm{~W}+1 \mathrm{H})$ pada Divisi Wire Rod Mill (Studi Kasus: PT. Krakatau Steel Tbk). Surakarta: Universitas Muhammadiyah Surakarta (2014)

7. J. Susetyo, Winarno, H.A. Wahyuni, Aplikasi Six Sigma DMAIC dan Kaizen Sebagai Metode Pengendalian dan Perbaikan Kualitas Produk. Jurnal Teknologi, 4 (1), Juni 2011, 61-53 (2011)

8. J. Antony, M. Kumar, C.N. Madu, Six Sigma in small and medium sized UK manufacturing enterprises : Some empirical observations. Int. J. of Quality and Reliability Management. 22(8), 860-874 (2005)

9. A. Syukron, M. Kholil, Six Sigma Quality For Business Improvement, Jakarta: Graha Ilmu (2012)

10. A.Fauziah, A. Harsono, G.P. Liansari, Usulan Perbaikan Kualitas Menggunakan Metode Six Sigma Untuk Mengurangi Jumlah Cacat Produk Tahu Pada Perusahaan Pengrajin Tahu Boga Rasa, J. Online Institut Teknologi Nasional, 2(4) (2014)

11. I. Vitho, E. Ginting, Anizar, Aplikasi Six Sigma Untuk Menganalisis Faktor-Faktor Penyebab Kecacatan Produk Crumb Rubber Sir 20 Pada PT. XYZ, Jurnal Teknik Industri FT USU, 3 (2013)

12. R.K. Aslani, A hybrid of fuzzy FMEA-AHP to determine factors affecting alternator failure causes, Management Science Letters, 1981-1984 (2014)

13. E.B. Beşikçi, T. Kececi, O. Arslan, O. Turan,. An Application of Fuzzy-AHP to Ship Operational Energy Eficiency Measures, Ocean Engineering, 121, 392-402 (2016)

14. A. Basuki, Manajemen Resiko Kerusakan Di Unit Pengemasan Pt.Semen Indonesia, Tbk, Pabrik Tuban. Prosiding Seminar Nasional Manajemen Teknologi XXII (hal. 1-6). Surabaya: Program Studi MMT-ITS (2015) 